\title{
TRASH DISPOSAL AND ITS RELATION TO CANE YIELD, SOIL AND WATER LOSSES
}

\author{
J. A. BONNET, F. ABRUÑA, ANd M. A. LUGO LÓPEZ*
}

\section{INTRODUCTION}

Some sugar producing countries prefer to burn the trash after the sugar cane harvest to facilitate subsequent cultivation operations of the crop and reduce the production cost. In Hawaii it is burned based on claims that the cane roots remaining in the soil are sufficient to maintain the organic matter requirements. In their fertilized cane fields no reduction of yield has been obtained following this practice.

In Puerto Rico, all the trash is burnt at the end of a final crop when the field is to be ploughed for a new planting and some farmers prefer to burn the cane just before harvesting every crop, especially on poorly drained lowlands or when the cane is a variety with unfavorable characteristics, such as dry leaves adhering to the stalk or leaves containing prickly hairs. However, there are some large cane plantations in the south coast that incorporate the trash to the soil with heavy equipment, like a Gyro-tiller, while plowing the field. In ratoon cultivation, it is a general practice in Puerto Rico to aline the trash in alternate rows. The reasons why this practice is followed are based on observations that the trash as a mulch conserves soil moisture and checks weed growth. It has been also reported that borer infestation of the cane fields increases after trash burning, because the borer parasites are destroyed. The studies on the decomposition of the various organic fractions: fats, sugars, cellulose, hemicellulose, lignin, proteins; and of the ash contents; in sugar cane trash, in the absence or presence of additional inorganic nitrogen, as done by Bonnet (1) have provided information which contribute to the proper understanding of the role of cane trash in the soil.

The results of a field experiment, performed in the Agricultural Experiment Station of the University of Puerto Rico, on level Vega Baja silty clay, indicated that no significant differences are to be expected between the mean cane yields of four consecutive crops of cane when the trash is either burned or buried in each bank, or alined in alternate banks. For longer periods of time, however, the cumulative effects of these treatments might be different.

This paper presents data on the use of sugar cane trash as a mulch and its

* Head, Soils Department; formerly Asst. Soil Conservationist, now Soil Scientist with the B.P.I.-S.C.S. cooperative Research Project; and Associate Soil Scientist, respectively, Agricultural Experiment Station, University of Puerto Rico. 
effect on soil and water losses in sloping land with the objective of rating its value as a soil conservation practice.

\section{EXPERIMENTAL}

Twelve plots, each with an approximate slope of 40 per cent, were selected at Las Ochenta farm in Mayaguez, (photo 1), where the Soil Conservation run-off plots with catchment tanks were located. The soil was a Catalina clay (2), a reddish brown lateritic soil, very deep, strongly acid, low in total exchange capacity, nitrogen, phosphorus and lime.

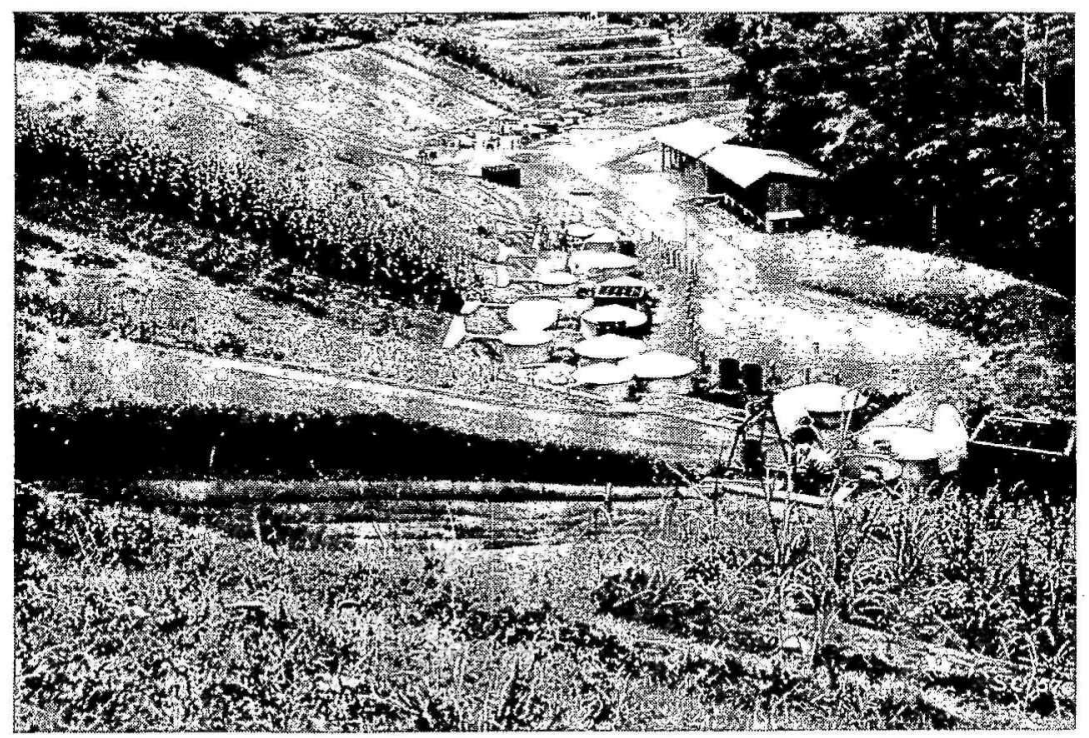

Рното 1. Soil conservation run-off plots with catchment tank at Las Ochenta farm, Mayagüez. Photo taken before the trash experiment.

The size of each plot was 12 feet wide by 56.3 feet long. The limits of each plot were protected with a galvanized zinc border down to six inches into the ground and a funnel shape apron connected to the first catchment tank, (photo 2). The plots were separated by a border row. The second catchment tank collected one-ninth or one-seventh of the excess of water and soil running off from the first one, (photo 3 ).

Thirty-nine holes, 18 inches wide, 24 inches long and six inches deep were dug in each plot at a semi-staggered pattern in each of 13 tiers placed at four feet apart. The plots were planted to POJ 2878 cane on March 1944, placing four cane seedlings at the corners of each hole. Four consecutive crops of cane were harvested in the dates reported in table 1 . Weeding and cultiva- 


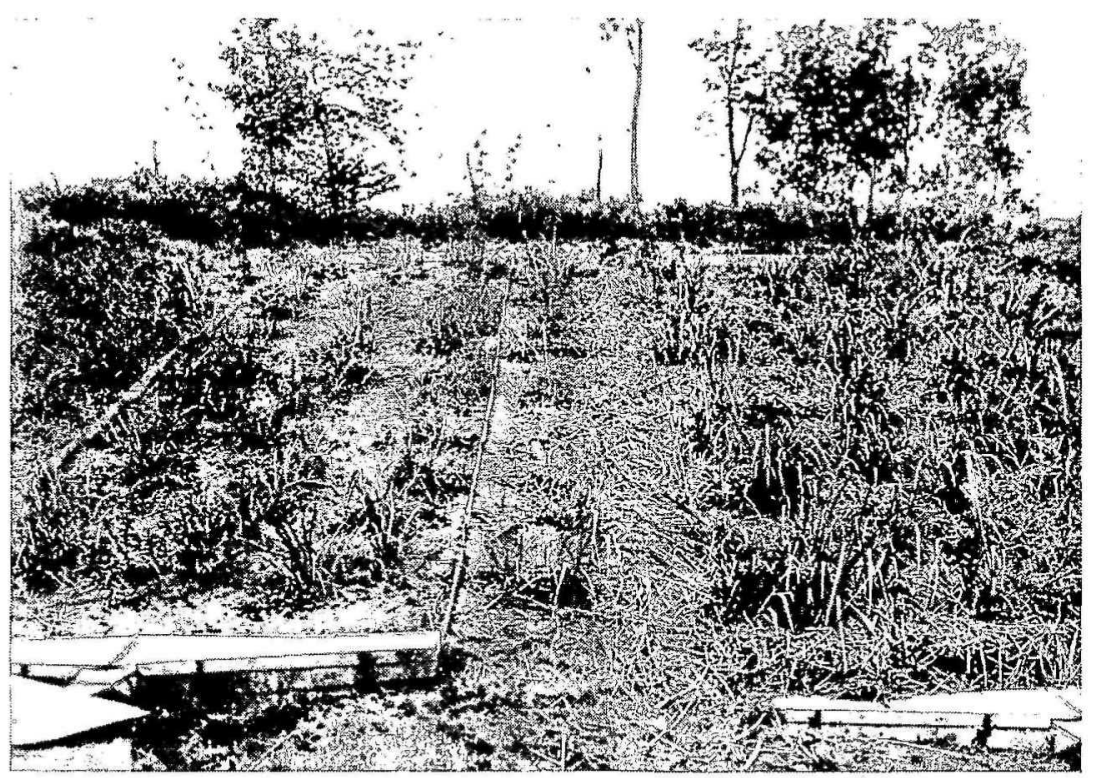

Рноту 2. Unmulched sugar cane plot at the left and mulched one at the right. See galvanized zinc border around the plot with apron at the front connected to first tank. Photo taken for third ratoon crop 11 days after previous harvest.

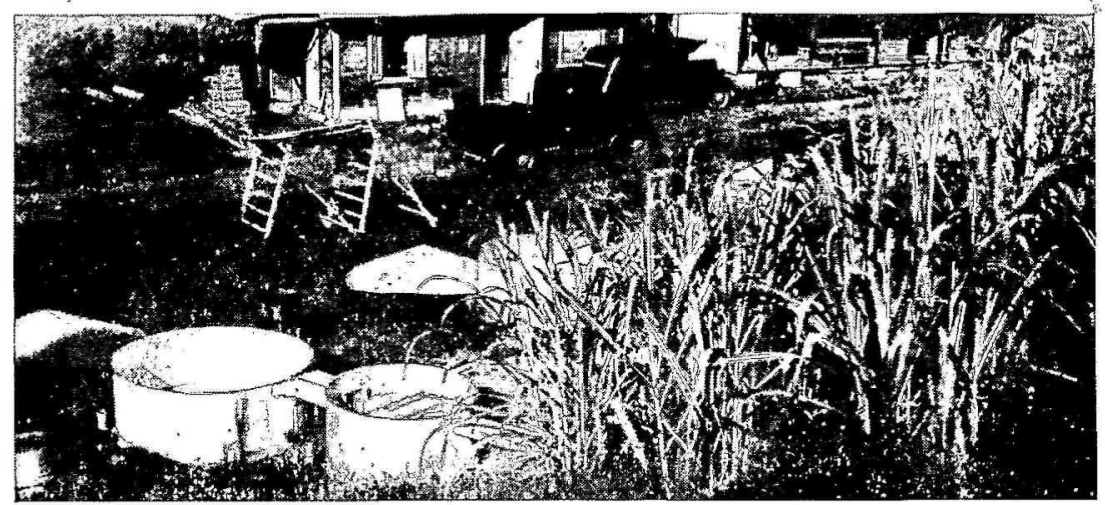

Рното 3. Unmulched plot after a 3.30 inch rain. Observe settling and sample tanks full with run-off water.

tion were done with a hand hoe. Each of the first three cane crops received a 14-6-8 fertilizer at the rate of 1200 pounds to the acre. The last crop received half this amount.

The plots were grouped into six blocks of two adjacent plots each. Before 
planting, all plots were covered with dry sugar cane trash at the rate of five tons to the acre. In one plot from each block, the trash was burned, and in other one, it was accumulated in a continuous row just below each tier of holes and was allowed to decompose. Similar treatment was given to the trash produced from each of the first three crops of cane. The harvesting and weighing of the cane and trash from all the plots were done simultaneously. The sugar yield of the cane was also determined. The area of each plot used for transferring yields into the acre basis was approximately oneseventieth of an acre after reducing the length of the plot to 52.3 feet and discarding the areas within two feet from each end.

The first year, the soil and water losses were recorded after each rain. From the second year on they were recorded monthly and also every time the tanks were full with water. At time of sampling the soil in the bottom of each tank was stirred to an uniform suspension. All the suspension from each tank was collected in tared buckets and weighed separately. From each bucket, two one-quart bottles were collected for sampling. All the subsamples were stirred together and final duplicate one-quart samples were collected in tared bottles for the laboratory. After weighing the bottles, the suspension was dispersed by adding one milliliter of a sodium hydroxide concentrated solution. Then, the soil in the suspension was precipitated by adding three milliliters of a normal aluminum sulphate coagulating solution. The samples were left overnight and the supernatant clear solution was syphoned off the next day. The soil was transferred to tared aluminum cans and dried in an oven to $105^{\circ} \mathrm{C}$ to constant weight. Data were calculated on the basis of soil and water losses per plot and per acre.

Available phosphorus, ammonia and nitrate nitrogen were determined in the water and soil losses from the mulched and unmulched plots, for the period of June 13 to August 29, 1944, after the first crop was fertilized.

Composite soil samples from the top, middle, and end, of each plot at $0-3,3-6,6-12$, and $18-36$ inches of depth were taken after the last harvest. Determinations were made for $\mathrm{pH}$, total nitrogen and organic matter. The total nitrogen was determined by the Kjeldahl method and the organic matter by the Walkley and Black's modification of Shollenberger's method (3).

\section{PRESENTATION OF DATA AND DISCUSSION}

The rainfall for the growing periods varied from 61 to 82 inches and from 0.19 to 0.26 inch per day, (table 1 ). The youngest crop, the first ratoon, received the highest rainfall, 82 inches, and the oldest one, the third ratoon, received the least, 61 inches. The total mean rainfall received by the four cane crops was 71.29 inches or 0.20 inch per dily.

No significant difference was found between the yields of cane and sugar 
and the water loss of the unmulched and mulched treatments (table 2). But there was a highly significant difference between the soil losses; in general, it was eleven times higher for the unmulched treatment.

The mean yield of trash was about 5 tons of dry material or one-fifth of the cane tonnage. This value does not include the weights of the green tops

TABLE 1

Age of POJ 2878 cane crops and rainfall received by crop for the growing period and per day

\begin{tabular}{|c|c|c|c|c|}
\hline Crop & Growing Period & $\begin{array}{l}\text { Age of } \\
\text { crop } \\
\text { (days) }\end{array}$ & $\begin{array}{l}\text { Rainfall } \\
\text { (inches) }\end{array}$ & $\begin{array}{l}\text { Inches of } \\
\text { rainfall } \\
\text { per day }\end{array}$ \\
\hline Plant crop & March 30, 1944 to April 11, 1945 & 377 & 75.01 & 0.20 \\
\hline 1st. Ratoon & April 11, 1945 to February 19,1946 & 314 & 82.19 & 0.26 \\
\hline 2nd. Ratoon & February 19, 1946 to February 13,1947 & 360 & 68.83 & 0.19 \\
\hline 3rd. Ratoon & February 13,1947 to March 3,1948 & 383 & 61.02 & 0.16 \\
\hline \multicolumn{2}{|c|}{ Weighted mean } & 358 & 71.29 & 0.20 \\
\hline
\end{tabular}

TABLE 2

Trash, cane and sugar yields, soil and water losses from mulched and unmulched treatments of the four sugar cane crops

\begin{tabular}{|c|c|c|c|c|c|c|c|}
\hline Crop No. & & Treatment & $\begin{array}{l}\text { Dry trash } \\
\text { tons/acre }\end{array}$ & Cane tons/acre & $\begin{array}{c}\text { Sugar } \\
\text { tons/acre }\end{array}$ & $\begin{array}{l}\text { Soil losses } \\
\text { tons/acre }\end{array}$ & $\begin{array}{l}\text { Water } \\
\text { losses } \\
\text { inches }\end{array}$ \\
\hline \multirow[t]{2}{*}{1} & $\begin{array}{l}\text { Plant } \\
\text { cane }\end{array}$ & Mulched & 5.09 & 24.60 & 3.15 & 0.79 & 4.56 \\
\hline & $\begin{array}{l}\text { Plant } \\
\text { cane }\end{array}$ & Unmulched & 4.51 & 24.99 & 3.22 & 9.88 & 4.22 \\
\hline \multirow[t]{2}{*}{2} & Ratoon & Mulched & 4.98 & 28.52 & 3.63 & 1.22 & 8.65 \\
\hline & Ratoon & Unmulched & 4.78 & 32.40 & 4.06 & 16.17 & 8.52 \\
\hline \multirow[t]{2}{*}{3} & Ratoon & Mulched & 5.33 & 31.89 & 4.06 & 0.50 & 4.50 \\
\hline & Ratoon & Unmulched & 5.14 & 31.82 & 4.29 & 3.11 & 3.60 \\
\hline \multirow[t]{4}{*}{4} & Ratoon & Mulched & 5.22 & 18.20 & 2.36 & 0.29 & 3.46 \\
\hline & Ratoon & Unmulched & 4.97 & 20.30 & 2.36 & 1.34 & 3.45 \\
\hline & Weighted & Mulched & 5.16 & 25.60 & 3.27 & 0.67 & 5.12 \\
\hline & mean. . & Unmulched & 4.85 & 27.07 & 3.52 & 7.20 & 4.77 \\
\hline
\end{tabular}

of the cane which were $6.85,5.77$ and 3.47 tons to the acre, for the first, second and third crops, respectively. These tops were removed because it is a common practice in the sugar cane fields to use them as fodder for cattle.

The mean water loss (table 2) from the soil with a 40 percent slope was 4.94 inches for all the four crops. This water loss represents about one- 
fourteenth of the total rainfall, a low figure. The bulk of the water, 66.35 inches, was transpired by the cane crop, evaporated from the soil, trash and leaves, and infiltered into the soil. On the basis that one inch of water is equivalent to 226,875 pounds to the acre, the 66.35 inches amount to 7,527 tons of water or a consumption of 286 tons of water per ton of cane on the basis of a mean yield of 26.33 tons of cane for the four crops.

TABLE 3

Water and soil losses; and losses of phosphorus, ammonia and nitrate nitrogen in run-off waters and eroded soil during the period of June 13 to August 29, 1944 from mulched and unmulched plots

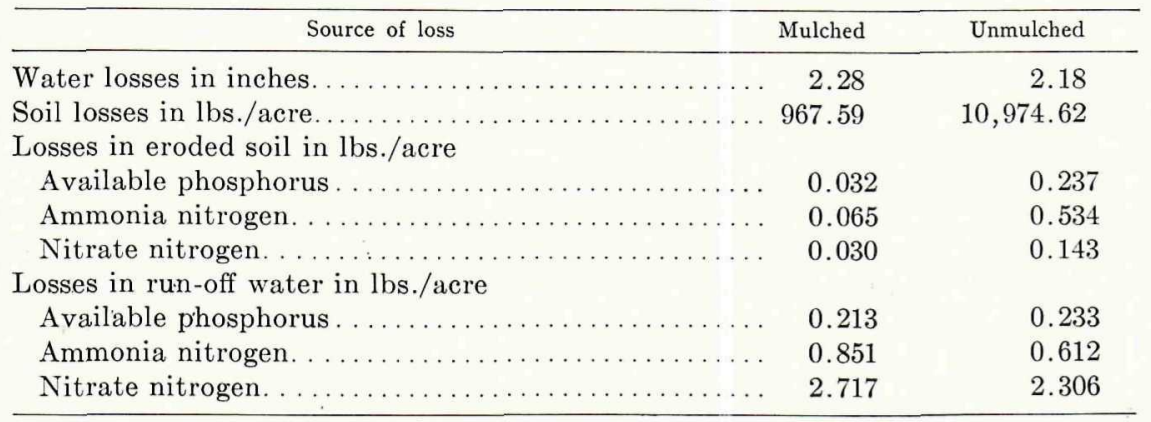

TABLE 4

Values for $p H$, nitrogen, and organic matter at various depths in mulched and unmulched plots

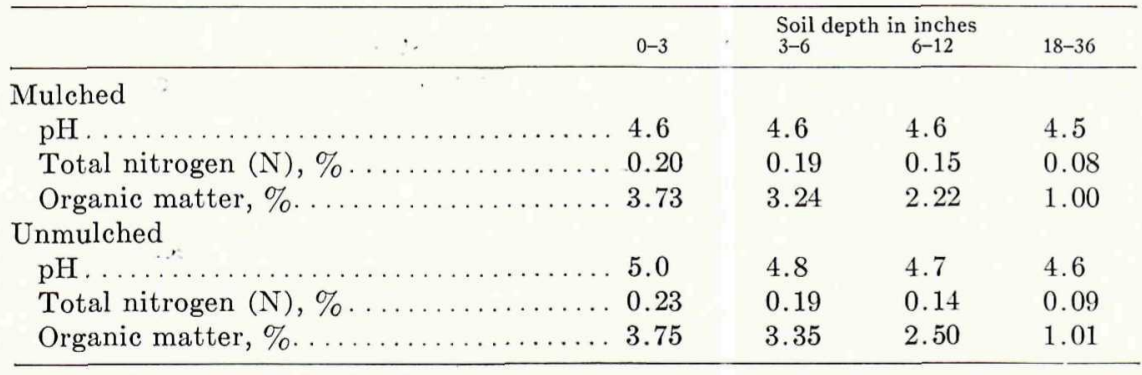

The 4.77 inches of water lost in the unmulched treatment are equivalent to 541.1 tons to the acre. This amount of water carried from the unmulched plots, 7.20 tons of soil forming a turbid suspension with about 13,306 parts per million of sediments. Clearer waters were running from the mulched plots with a content of about 1,153 parts per million of sediments. The trash, if it were kept as a mulch on the sloping area of lateritic soils that are planted to sugar cane, would contribute toward decreasing the turbidity of the reddish waters that run through the drainage channels and rivers in 
times of heavy rains. Turbid waters require more alum in the aqueduct plants during the sedimentation process and thereby decrease their efficiency of operation. The trash as a mulch would therefore contribute toward the improvement of water supplies for human consumption.

The losses of available phosphorus, ammonia and nitrate nitrogen (table 3 ) in the soil eroded and water run-off, for the 46-day period recorded, were very small. The losses of phosphorus and ammonia were about eight times higher in the eroded soil from the unmulched plots and the nitrate losses were about five times higher.

The values obtained for $\mathrm{pH}$, total nitrogen and organic matter (table 4) at the four depths reported are about the same for the mulched and unmulched plots. The trash as a mulch did not contribute toward raising the soil organic matter content during the four year period when four crops of cane were harvested.

\section{SUMMARY}

The effect of leaving the trash as a mulch or burning it, for each of four crops of sugar cane growing in a lateritic soil with a 40 percent slope, has been compared with respect to cane and sugar yield and soil and water losses. No significant difference was found between the cane and sugar yield and the water losses between the mulched and unmulched treatments. But a highly significant difference was found between soil losses; it was about 11 times higher for the unmulched plots.

The amount of water consumed per ton of cane was estimated to be 286 tons.

The losses of available phosphorus, ammonium and nitrate, were very small in the eroded soil and water run-off. The mulching was not effective in raising the soil organic matter.

\section{ACKNOWLEDGMENT}

To Mr. Pedro Tirado Sulsona, formerly Assistant Soil Conservationist, Soils Department, Agricultural Experiment Station, for his help in the field work in connection with the first crop, 1944-1945; and for laboratory analyses of samples taken after the last crop was harvested.

This work was undertaken in cooperation with the Soil Conservation Service of Puerto Rico, of which Mr. E. A. Telford, Assoc. Soil Conservationist, was in charge of the field experiments at Mayagüez, and with the Federal Experiment Station that provided land and office space at Mayagüez.

\section{RESUMEN}

En un suelo laterítico con una pendiente de 40 por ciento se comparó el efecto de dejar la paja de caña como mulla sobre el terreno y quemarla, en 
los rendimientos de caña y azúcar y en las pérdidas de suelo por erosión de aguas de escorrentía. Los datos incluyen cuatro cosechas consecutivas de caña de azúcar.

Los resultados indican que no hubo diferencia entre los rendimientos de caña y azúcar y las pérdidas de agua debido a los dos tratamientos. Sin embargo, hubo una diferencia muy significativa entre las pérdidas de suelo por erosión. Estas fueron once veces mayores en las parcelas donde se quemó la paja.

El consumo de agua se estimó en 286 toneladas por tonelada de caña.

Las pérdidas de fósforo, amonio y nitrato asimilables en el suelo arrastrado por la erosión y en las aguas de escorrentía fueron muy bajas. El tratamiento de mulla no aumentó la materia orgánica del suelo.

\section{LITERATURE CITEI)}

1. Bonnet, J. A., Nitrogen transformation in the decomposition of sugar cane trash, with special bearing upon Puerto Rico soil problems. Jour Dept. Agr. P. R. 15(2): 113-146. 1941.

2. Roberts, R. C., et a!., Soil Survey of Puerto Rico. U.S.D.A. Bur. of Pl. Ind. in Coop. with P. R. Univ. Agr. Exp. Sta., series 1936, (8) 503 p. 1942.

3. Walkley, A., and Black, I. A., An examination of the Degtjareff method for determining soil organic matter, and a proposed modification of the chromic acid titration method. Soil Sc. $37: 29-38.1934$. 